\title{
Prediksi Laju Erosi dengan Menggunakan Metode RUSLE dan Penginderaan Jauh pada Sub DAS Bangkala
}

\section{(Prediction of Erosion Rate Using the RUSLE Method and Remote Sensing in Bangkala Sub-watershed)}

\author{
Fitriani $^{{ }^{1 *} \text {, }}$, Sitti Nur Faridah ${ }^{2)}$ dan Daniel Useng ${ }^{3)}$ \\ 1) Program Studi Keteknikan Pertanian Universitas Hasanuddin \\ 2) Program Studi Keteknikan Pertanian Universitas Hasanuddin \\ 3) Program Studi Keteknikan Pertanian Universitas Hasanuddin \\ ${ }^{*}$ Email korespondensi: fitrianitekpert14@yahoo.com
}

\begin{abstract}
ABSTRAK
Sungai merupakan salah satu unsur penting dalam kehidupan manusia yaitu sebagai penampung air hujan, pusat dari ekosistem, mencegah terjadinya banjir dan sebagai sumber air irigasi. Daerah aliran sungai ini dapat menyebabkan terjadinya erosi tanah. Erosi adalah suatu proses alam yang terjadi secara alami, tetapi pada umumnya dipercepat oleh berbagai aktivitas-aktivitas manusia. Efek yang ditimbulkan dari erosi tanah adalah kerugian terhadap hilangnya lapisan subur permukaan tanah untuk kegiatan pertanian, terjadinya penggerusan lapisan tanah, lepasnya partikel tanah yang menyebabkan terjadinya sedimentasi ke arah muara sesuai arah aliran sungai. Pendugaan erosi dapat dilakukan dengan menggunakan metode RUSLE. Tujuan dari penelitian ini adalah untuk memprediksi laju erosi di Sub DAS Bangkala dengan menggunakan metode RUSLE dan penginderaan jauh. Erosi dengan kelas sangat ringan memiliki persentase yang lebih besar yaitu 36,50\% dengan luas wilayah 391,12 ha dibandingkan dengan tingkat erosi lainnya. Hasil yang didapatkan menunjukkan bahwa laju erosi rata-rata yang terjadi pada sub DAS Bangkala yaitu 56,05 ton/ha/tahun dimana faktor yang paling berpengaruh terhadap besarnya erosi pada penelitian ini adalah faktor kemiringan lereng dan faktor penutupan lahan.
\end{abstract}

Kata Kunci: Erosi, RUSLE, Daerah Aliran Sungai (DAS).

\section{PENDAHULUAN}

\section{Latar Belakang}

Sungai sebagai salah satu unsur penting bagi kehidupan manusia yaitu sebagai penampung air hujan, pusat dari ekosistem, mencegah terjadinya banjir dan sebagai sumber air irigasi. Daerah aliran sungai ini dapat menyebabkan terjadinya erosi tanah karena beberapa faktor antara lain intensitas hujan yang tinggi dapat menyebabkan kecepatan aliran meningkat sehingga tanah akan tergerus atau terkikis yang dikenal dengan erosi.
Erosi tanah adalah masalah serius yang timbul dari intensifikasi pertanian degradasi lahan dan lainnya (Fahliza, 2013). Erosi tidak dapat dihindari karena erosi merupakan proses alam yang berlangsung secara alami. Dampak yang dari erosi tanah hilangnya lapisan subur permukaan tanah dalam aktivitas pertanian, tergerusnya lapisan tanah, lepasnya butiranbutiran tanah sehingga terjadi sedimentasi ke arah muara sungai yang mengakibatkan kapasitas aliran pada sungai berkurang, kemungkinan terjadinya banjir lebih besar dan terjadinya pendangkalan pada daerah aliran sungai. Sebagai salah satu negara 
tropis basah Indonesia berada pada peringkat yang cukup tinggi pada laju erosi alami dan pertanaman yaitu 2-3 ton/ha/thn untuk keadaan alami, 40-400 ton/ha/thn pada area pertanaman dan memiliki laju erosi terbesar kedua pada area tanah gundul yaitu sebesar 120-460 ton/ha/thn (Nugroho, 2014). Proses sedimentasi di perairan dapat menimbulkan pendangkalan dan penurunan kualitas air dimana tingginya konsentrasi sedimen dalam badan air akan menyebabkan kekeruhan.

Salah satu kasus sedimentasi akibat proses erosi yaitu pada sub DAS Bangkala di sekitar pertambakan garam yang terletak di Kecamatan Bangkala Kabupaten Jeneponto. Berdasarkan survei langsung di lapangan kondisi sub DAS tersebut sangat berlumpur dikarenakan banyaknya sedimen yang masuk ke pertambakan garam sehingga menghambat air yang masuk ke tambak yang menyebabkan produktivitas tambak menurun dan ketika musim hujan daerah tersebut terendam banjir. Kualitas lingkungan sekitar yang semakin buruk, termasuk kualitas lingkungan yang buruk akibat pendangkalan di saluran-saluran air. Hutan mangrove yang dulu banyak ditemukan di sekitar pesisir pantai sumber air baku tambak kini mulai berkurang karena terjadi erosi di sekitar tambak serta upaya penanaman mangrove yang gagal (Candra, 2017).

Berdasarkan uraian diatas maka perlu dilakukan penelitian tersebut untuk mengetahui seberapa besar laju erosi yang terjadi pada Sub DAS Bangkala.

\section{Tujuan dan Kegunaan}

Tujuan dari penelitian ini adalah untuk memprediksi laju erosi di Sub DAS Bangkala dengan menggunakan metode RUSLE dan penginderaan jauh.

Kegunaan dari penelitian ini adalah untuk memberikan informasi kepada masyarakat maupun instansi terkait tentang bahaya erosi sehingga dapat dilakukan arahan konservasi tanah dan pengelolaan pada Sub DAS Bangkala dengan baik.

\section{METODOLOGI PENELITIAN}

\section{Alat dan Bahan}

Alat yang digunakan pada penelitian ini adalah, software ArcGIS 10.3, Microsoft office Excel, Global Mapper, Google Earth, Ring sample, plastik sample, satu unit Laptop, kamera, cangkul dan linggis.

Bahan yang digunakan pada penelitian ini peta jenis tanah, peta penutupan lahan, peta kelerengan yang diperoleh dari Aster Digital Elevation Model (DEM), data curah hujan bulanan (10 tahun terakhir) peta administrasi DAS Puncaca dan sampel tanah.

\section{Prosedur Penelitian}

Prosedur pada penelitian ini dilakukan dengan menentukan lokasi penelitian untuk penentuan titik sampling, kemudian mengumpulkan data-data yang berkaitan dengan penelitian. Data-data tersebut selanjutnya dianalisis dan diolah di ArcGIS untuk mendapatkan peta erosi.

\section{Penentuan Lokasi Penelitian}

Penentuan lokasi penelitian dilakukan dengan terlebih dahulu mendeliniasi batas Sub DAS Bangkala. kemudian melakukan overlay terhadap peta kelerengan, peta jenis tanah, peta curah hujan dan peta penutupan lahan untuk membuat peta unit lahan.

\section{Pengumpulan Data}

Tahap ini merupakan tahap pengumpulan data-data yang akan mendukung pelaksanaan penelitian. Datadata yang diperlukan meliputi :

\section{Data Curah Hujan}

Data curah hujan yang digunakan dalam penelitian ini diperoleh dari Dinas Sumberdaya Air, Cipta Karya \& Tata Ruang Provinsi Sulawesi Selatan yang selanjutnya digunakan dalam penentuan nilai erosivitas.

2. Data Jenis Tanah

Pengumpulan data jenis tanah dilakukan dengan dua cara yaitu data jenis tanah yang diperoleh dari data sistem lahan (landsystem) Regional Physical Project For Transmigration (RePPProt) Badan Koordinasi Survey dan Pemetaan Nasional, dan data jenis tanah yang diperoleh dengan 
mengambil sample tanah menggunakan ring sample. Jenis tanah selanjutnya dijadikan acuan dalam penentuan nilai erodibilitas tanah pada lokasi penelitian.

3. Data Kelerengan

Data kelerengan diperoleh dari data Aster DEM yang disediakan oleh United States Geological Survey (USGS), data ini selanjutnya akan digunakan untuk penentuan nilai LS (Land Slope).

4. Data Pengelolaan Tanaman dan Tindakan Konservasi Tanah

Data penutupan lahan diperoleh dari Google Earth yang kemudian dilakukan proses digitasi. Pengumpulan data dan pengamatan kondisi penutupan lahan serta tindakan konservasi tanah dilakukan pada unit lahan yang telah ditentukan sebelumnya serta melakukan pengamatan langsung di lapangan. Data yang diperoleh dari pengamatan ini akan digunakan untuk penentuan nilai faktor $\mathrm{C}$ dan $\mathrm{P}$.

\section{Analisis Data}

Untuk mengetahui besarnya erosi (A) maka dilakukan analisis terhadap faktorfaktor penentu erosi yaitu R (Erosivitas), K (Indeks erodibilitas), LS (Indeks panjang dan kemiringan lereng), C (Indeks penutupan vegetasi dan pengelolaan tanaman) dan $\mathrm{P}$ (Indeks Pengelolaan lahan/tindakan konservasi tanah) pada setiap unit lahan yang telah dibuat sebelumnya menggunakan metode RUSLE yang dikembangkan oleh Wischmeier dan Smith (1978), dengan persamaan berikut.

$$
\mathrm{A}=\mathrm{R} \times \mathrm{K} \times \mathrm{LS} \times \mathrm{C} \times \mathrm{P}
$$

Keterangan :

$\mathrm{A}=$ banyaknya tanah tererosi dalam ton/ha/tahun (laju erosi)

$\mathrm{R}=$ faktor erosivitas hujan

$\mathrm{K}=$ faktor erodibilitas tanah

$\mathrm{LS}=$ faktor panjang dan kemiringan lereng

$\mathrm{C}=$ faktor penutupan vegetasi dan pengelolaan tanaman

$\mathrm{P}=$ faktor pengelolaan lahan/tindakan konservasi

\section{Faktor Erosivitas Hujan}

Erosivitas hujan merupakan kemampuan hujan dalam mengerosi tanah. Untuk metode RUSLE nilai erosivitas dihitung dengan menggunakan rumus Lenvain. Adapun persamaan matematisnya sebagai berikut:

$$
\mathrm{R}_{\mathrm{b}}=2,21(\text { Rain) })^{1,36}
$$

Keterangan :

$\mathrm{R}_{\mathrm{b}}=$ Erosivitas curah hujan bulanan

$(\text { Rain })_{b}=$ Curah hujan bulanan dalam $\mathrm{cm}$

\section{Faktor Erodibilitas Tanah}

Nilai faktor erodibilitas tanah ditentukan untuk tiap satuan lahan. Penetapan nilai faktor erodibilitas tanah diperoleh dengan menganalisis peta jenis tanah dan nilai erodibilitas setiap jenis tanah. Dari hasil analisis tersebut kemudian dicocokkan dengan tabel nilai $\mathrm{K}$ yang telah ditetapkan.

\section{Faktor Panjang dan Kemiringan Lereng $(L S)$}

Penetapan besarnya nilai faktor LS dengan menganalisis peta kelas lereng yang diperoleh dari analaisis data Aster DEM kemudian dicocokkan dengan tabel nilai LS. Nilai kelas kemiringan lereng dapat dilihat pada Tabel 1.

Tabel 1. Penilaian Kelas Kelerengan (LS)

\begin{tabular}{ccc}
\hline Kelas Lereng & $\begin{array}{c}\text { Kemiringan } \\
\text { Lereng (\%) }\end{array}$ & Nilai LS \\
\hline I & $0-8$ & 0,40 \\
II & $8-15$ & 1,40 \\
III & $15-25$ & 3,10 \\
IV & $25-40$ & 6,80 \\
V & $>40$ & 9,50 \\
\hline
\end{tabular}

\section{Indeks Penutupan Vegetasi dan \\ Pengolaan Lahan (CP)}

Penentuan nilai faktor CP dilakukan dengan menganalisis peta penutupan lahan dan melakukan pengamatan langsung di lapangan pada tiap unit lahan yang telah ditentukan, kemudian dicocokkan dengan tabel nilai $\mathrm{C}$ dan $\mathrm{P}$.

\section{Peta Erosi}

Untuk mendapatkan peta erosi, dilakukan overlay (tumpang tindih) terhadap peta erosivitas hujan, peta kelas lereng, peta jenis tanah dan peta penutupan lahan kemudian dianalisis menggunakan rumus RUSLE. 
Penentuan Nilai Erodibilitas Tanah (K) Menggunakan Sampel Tanah

Penentuan nilai erodibilitas tanah dapat ditentukan dengan menggunakan Nomograf sebagai berikut (Hardjowigeno, 2007).

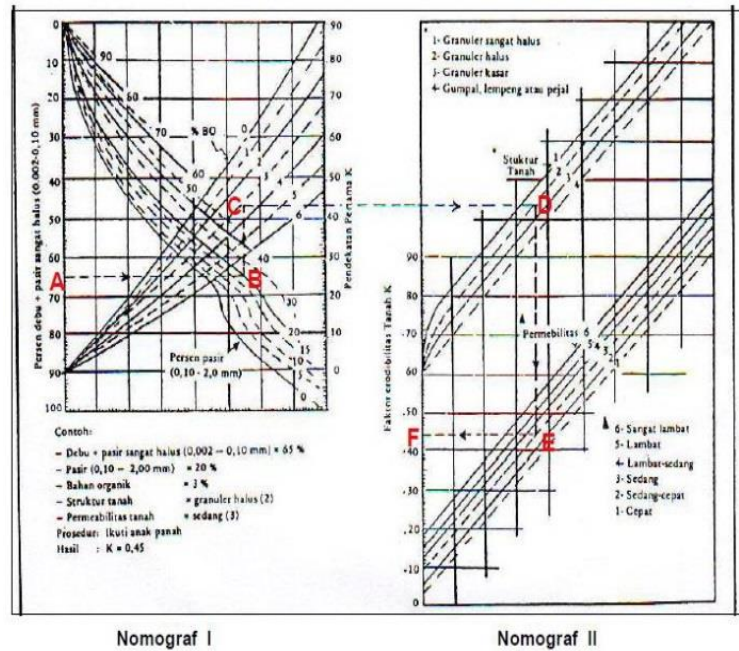

Gambar 1. Nomograf erodibilitas tanah

Penggunaan Nomograf dilakukan dengan terlebih dahulu menentukan:

1. Tekstur tanah di laboratorium

2. Bahan organik tanah di laboratorium

3. Permeabilitas tanah di laboratorium

4. Penentuan Struktur Tanah dengan cara:

a. Mengukur panjang, lebar dan ketebalan bongkahan tanah

b. Mengamati bentuk bongkahan mulai dari sisi dan bentuknya

c. Menggolongkan menurut jenis strukturnya

d. Mencatat hasil pengamatan

e. Mencocokkan hasil pengamatan dengan tabel berikut.

Tabel 2. Kode Tipe Struktur

\begin{tabular}{cc}
\hline Tipe Struktur & Kode \\
\hline Granular sangat halus & 1 \\
Granular halus & 2 \\
Granular sedang dan kasar & 3 \\
Gumpal, lempeng, pejal & 4 \\
\hline
\end{tabular}

\section{Diagram Alir Penelitian}

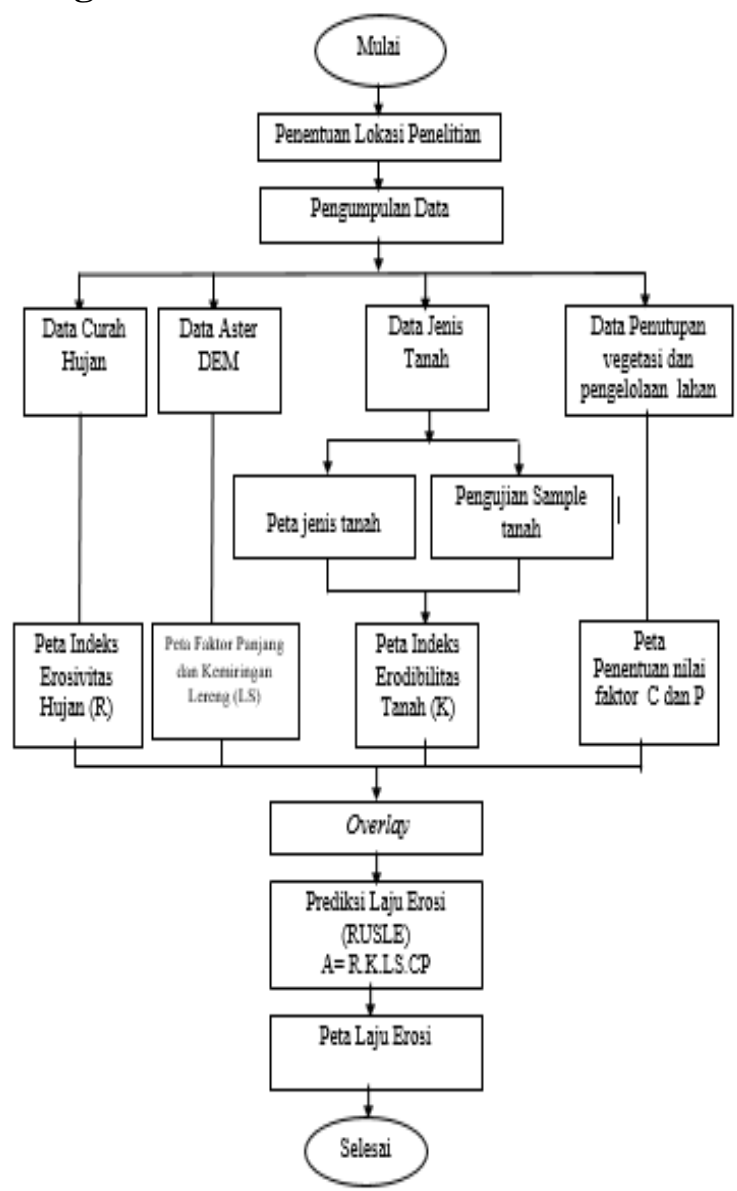

Gambar 2. Diagram Alir Penelitian

HASIL DAN PEMBAHASAN

\section{Keadaan Umum Lokasi}

Sub DAS Bangkala merupakan bagian dari DAS Puncaca yang secara administrasi terletak di Kecamatan Bangkala Kabupaten Jeneponto dengan letak geografis $119^{\circ} 33^{\prime} 00^{\prime \prime}-119^{\circ} 36^{\prime} 00^{\prime \prime}$ BT dan 5'35'0"-5'37'30" LS. Luas wilayah sub Das Bangkala yaitu 1071,62 ha, dimana di sebelah Utara berbatasan dengan Kecamatan Tompobulu Kabupaten Gowa dan sebelah Selatan berbatasan dengan Teluk Laikang. 


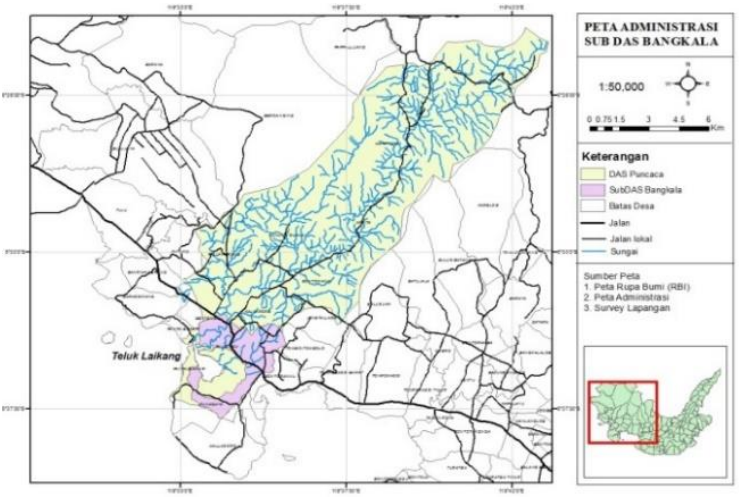

Gambar 3. Peta Administrasi Sub DAS Bangkala

Prediksi Erosi Metode Revised Universal Soil Loss Equation (RUSLE)

Faktor Erosivitas Hujan (R)

Nilai erosivitas hujan di wilayah sub

DAS Bangkala yaitu 782,75. Rata-rata curah hujan bulanan dapat dilihat pada Gambar 4.

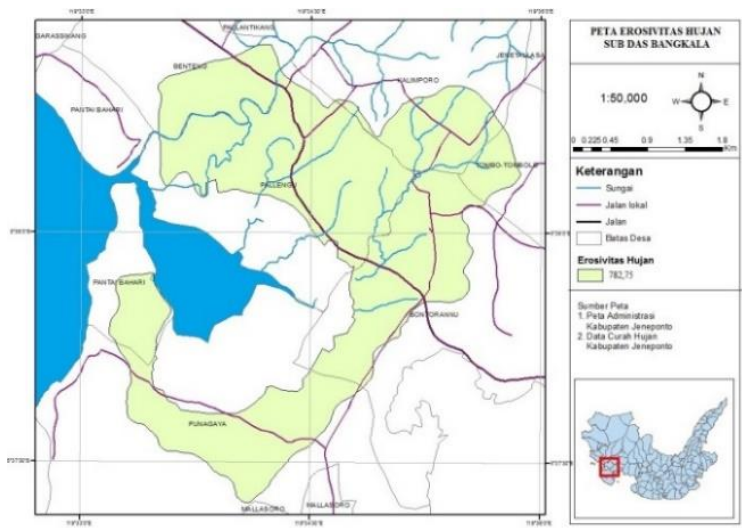

Gambar 4. Peta curah hujan bulan sub DAS Bangkala

Berdasarkan Gambar 4. dapat dilihat bahwa pada sub DAS Bangkala hanya satu stasiun hujan yang mencakup lokasi penelitian sehingga nilai erosivitas hujan tidak bervariasi, hal ini disebabkan karena letak stasiun curah hujan jauh dari lokasi penelitian. Berdasarkan data curah hujan yang di dapatkan dari Dinas Pengerjaan Umum, curah hujan tertinggi jatuh pada bulan Januari hingga Februari.

\section{Faktor Erodibilitas Tanah}

Adapun jenis tanah yang ada pada daerah sub DAS Bangkala dapat dilihat pada gambar 5 berikut ini.

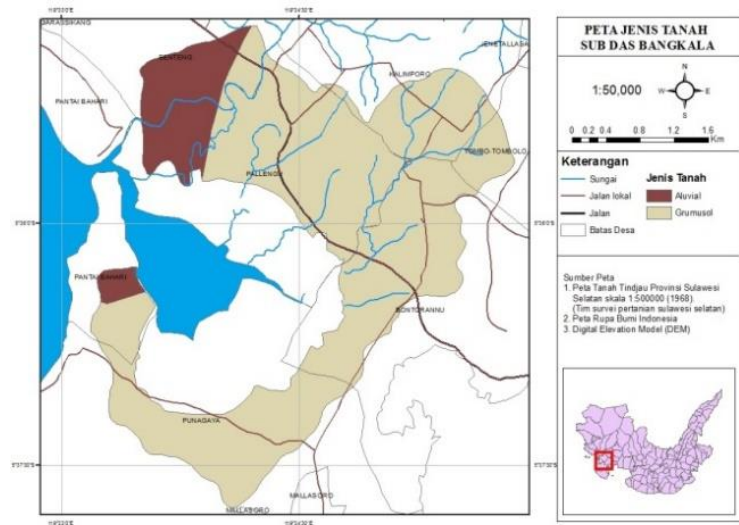

Gambar 5. Peta jenis tanah sub DAS Bangkala

Berdasarkan Gambar 5. dapat dilihat bahwa ada 2 jenis tanah yang ada di sub DAS Bangkala yaitu Aluvial dan Grumusol.

Tabel 3. Data jenis tanah sub DAS Bangkala

\begin{tabular}{ccc}
\hline Jenis Tanah & Area (ha) & Nilai K \\
\hline Aluvial & 143.98 & 0,47 \\
Grumusol & 927.64 & 0,20 \\
\hline
\end{tabular}

\section{Penentuan Nilai Erodibilitas Tanah Aluvial Menggunakan Nomograf}

Untuk mengetahui nilai erodibilitas jenis tanah yang ada pada sub DAS Bangkala dilakukan dengan menggunakan nomograf (Hardjowigeno, 2007) berdasarkan nilai persentasi debu, pasir, pasir sangat halus, bahan organik, nilai permeabilitas dan struktur tanah.

Penentuan nilai erodibilitas menggunakan nomograf untuk jenis tanah aluvial dengan persentase sebagai berikut.

- Debu + pasir halus $(68 \%+1 \%)=69 \%$

- Pasir = $4 \%$

- Bahan Organik = 3,19\%

- Struktur Tanah = Pejal (4)

- Permeabilitas Tanah = sedang-cepat (2)

- $\operatorname{Hasil}(\mathrm{K}) \quad=0,47$

Berdasarkan hasil yang didapatkan dengan menggunakan nomograf dapat diketahui bahwa nilai $\mathrm{K}$ untuk tanah aluvial berkisar antara 0,46-0,47 sesuai dengan Tabel 1 yang menunjukkan bahwa nilai $\mathrm{K}$ untuk tanah aluvial adalah 0,47. 


\section{Penentuan Nilai Erodibilitas Tanah Grumusol Menggunakan Nomograf}

Penentuan nilai erodibilitas untuk tanah grumusol, metode penggunaannya sama dengan tanah alluvial yaitu dengan menggunakan nomograf berdasarkan nilai persentase debu, pasir, pasir sangat halus, bahan organik, nilai permeabilitas dan struktur tanah.

Penentuan nilai erodibilitas menggunakan nomograf untuk jenis tanah grumusol dengan persentase sebagai berikut.

- Debu + pasir halus $(68 \%+1 \%)=51 \%$

- Pasir $=19 \%$

- Bahan Organik $\quad=2,79 \%$

- Struktur Tanah = Granular Kasar (3)

- Permeabilitas Tanah = sedang-cepat (2)

- $\operatorname{Hasil}(\mathrm{K}) \quad=0,27$

Hasil yang didapatkan dengan menggunakan nomograf (Lampiran 3) dapat diketahui bahwa nilai $\mathrm{K}$ untuk tanah grumusol berkisar antara 0,27 sesuai dengan Tabel 1 yang menunjukkan bahwa nilai $\mathrm{K}$ untuk tanah aluvial adalah 0,20 0,27 .

\section{Faktor Panjang dan Kemiringan Lereng (LS)}

Kemiringan lereng yang ada berkisar antara $0-8 \%$ (datar) dan 8-15\% (landai) hal ini karena lokasi penelitian berada di dataran rendah dengan ketinggian 0-100 M di atas permukaan laut.

Tabel 5. Data kelas kemiringan lereng sub DAS Bangkala

\begin{tabular}{cccc}
\hline $\begin{array}{c}\text { Kemiringan } \\
(\%)\end{array}$ & Keterangan & $\begin{array}{c}\text { Luas } \\
\text { (ha) }\end{array}$ & $\begin{array}{c}\text { Nilai } \\
\text { LS }\end{array}$ \\
\hline $0-8$ & Datar & 388,01 & 0,40 \\
$8-15$ & Landai & 376,22 & 1,40 \\
$15-25$ & Agak curam & 219,56 & 3,10 \\
$25-40$ & Curam & 77,74 & 6,80 \\
$>40$ & Sangat & 10,09 & 9,50 \\
& curam & & \\
\hline
\end{tabular}

\section{Faktor Panjang dan Kemiringan Lereng} (LS)

Kemiringan lereng yang ada kebanyakan berkisar antara $0-8 \%$ (datar) dan $8-15 \%$ (landai) hal ini karena lokasi penelitian berada di dataran rendah dengan ketinggian 0-100 $\mathrm{m}$ di atas permukaan laut.
Tabel 6. Nilai faktor berdasarkan panjang dan kemiringan lereng sub DAS Bangkala

\begin{tabular}{cccr}
\hline $\begin{array}{c}\text { Kemiringan } \\
(\boldsymbol{\%})\end{array}$ & Keterangan & $\begin{array}{c}\text { Nilai } \\
\text { LS }\end{array}$ & \multicolumn{1}{c}{$\begin{array}{c}\text { Luas } \\
\text { (ha) }\end{array}$} \\
\hline $0-8$ & Datar & 0,40 & 388,01 \\
$8-15$ & Landai & 1,40 & 376,22 \\
$15-25$ & Agak curam & 3,10 & 219,56 \\
$25-40$ & Curam & 6,80 & 77,74 \\
$>40$ & Sangat curam & 9,50 & 10,09 \\
\hline & Total & & 1071,62 \\
\hline
\end{tabular}

Menurut peryataan Kartasapoetra (2010), semakin besar kemiringan lereng maka semakin besar pula laju erosi yang dihasilkan. Kemiringan lereng yang lebih besar menyebabkan partikel tanah mudah lepas. Jika dilihat beradasarkan peta kemiringan lereng dapat dilihat bahwa nilai erosi dengan besar cukup tinggi yaitu 618,54 ton/ha/tahun terdapat pada daerah dengan ketinggian $25-45 \%$ dan $>45 \%$.

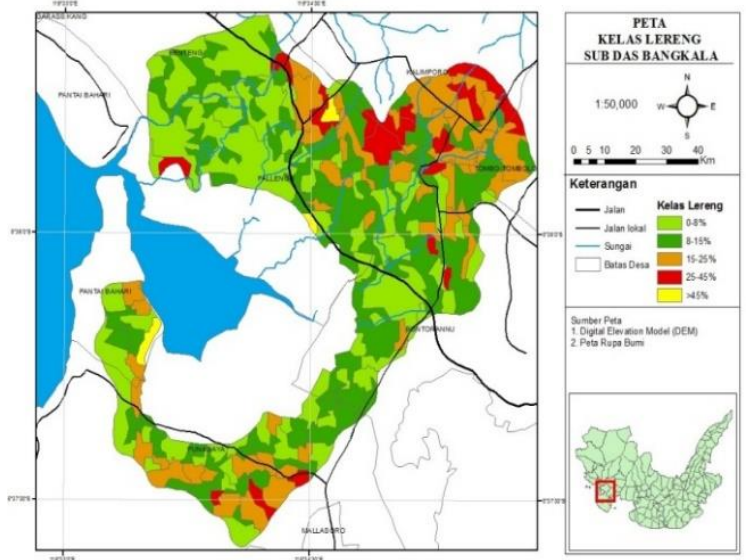

Gambar 6. Panjang dan Kemiringan Lereng Sub DAS Bangkala

\section{Faktor Penutupan Lahan}

Berdasarkan analisis faktor penutupan lahan $(\mathrm{CP})$ tersebut diketahui bahwa sub DAS Bangkala didominasi oleh pertanian lahan kering campur dengan luas 409,34 ha selanjutnya pertanian lahan kering dengan luas 392,07 ha.

Tabel 7. Nilai Faktor CP Untuk Berbagai Aspek Pengelolaan Lahan Sub DAS Bangkala

\begin{tabular}{lrr}
\hline \multicolumn{1}{c}{ Penutupan lahan } & Nilai CP & Luas (ha) \\
\hline Sawah & 0,1 & 161,89 \\
Pemukiman & 1 & 92,98 \\
Pertanian lahan & 0,5 & 392,07 \\
kering & &
\end{tabular}




\begin{tabular}{|c|c|c|}
\hline Penutupan lahan & Nilai CP & Luas (ha) \\
\hline Pertanian lahan & 0,1 & 409,34 \\
\hline kering campur & & \\
\hline Badan air & 0,0004 & 15,35 \\
\hline Total & & 1071,62 \\
\hline
\end{tabular}

Sebagian besar wilayah tersebut mempunyai musim kemarau yang lebih panjang. Oleh sebab itu pada sub DAS Bangkala didominasi oleh pertanian lahan kering dan pertanian lahan kering campur yang ditanami dengan jenis tanaman umur pendek saja. Adapun pembagian daerah penutupan lahan pada sub DAS Bangkala adalah sebagai berikut.

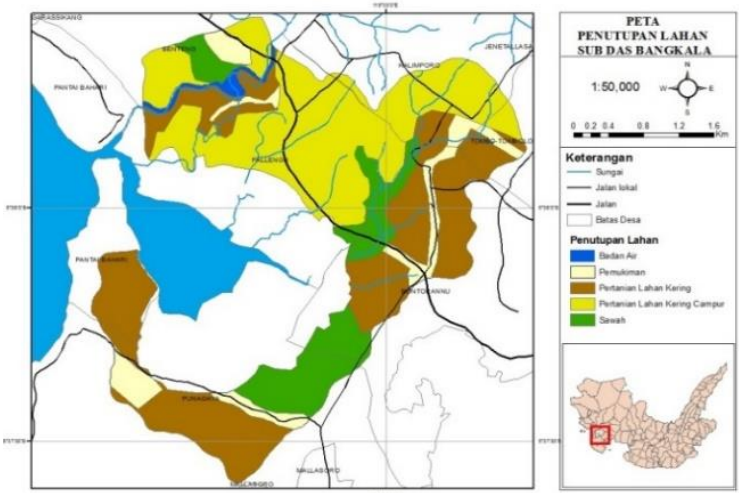

Gambar 7. Peta Penutupan Lahan Sub DAS Bangkala

\section{Analisis Model RUSLE}

\section{Klasifikasi Tingkat Bahaya Erosi (TBE) Sub DAS Bangkala}

Peta curah hujan, peta jenis tanah, peta panjang dan kemiringan lereng dan peta penutupan lahan dianalisis dengan menggunakan software ArcGIS 10.3 untuk mengetahui tingkat bahaya erosi yang terjadi di sub DAS Bangkala. Berikut adalah peta hasil overlay yang dilakukan dengan menggunakan metode RUSLE.

Tabel 8. Tingkat Bahaya Erosi Sub DAS Bangkala

\begin{tabular}{lrr}
\hline \multicolumn{1}{c}{ Kelas Erosi } & Luas (ha) & \% \\
\hline Sangat ringan & 391,12 & 36,50 \\
Ringan & 303,59 & 28,33 \\
Sedang & 320,47 & 29,91 \\
Berat & 53,25 & 4,97 \\
Sangat berat & 3,19 & 0.30 \\
\hline \multicolumn{1}{c}{ Total } & 1071,62 & 100 \\
\hline
\end{tabular}

Berdasarkan Tabel 8 dapat dilihat bahwa erosi dengan kelas sangat ringan memiliki persentase yang lebih besar yaitu $36,50 \%$, erosi dengan kelas ringan dan sedang mempunyai persentase yang hampir sama yaitu $28.33 \%$ dan $29,91 \%$. Terdapat erosi dengan kelas erosi sangat berat namun persentasenya hanya $0.30 \%$ dengan luas 3,19 ha dan untuk erosi dengan kelas erosi berat sebanyak 4,97\% dengan luas 53,19 ha. Dari hasil tersebut dapat diketahui laju erosi rata-rata yang terjadi pada sub DAS Bangkala yaitu 56,05 ton/ha/tahun.

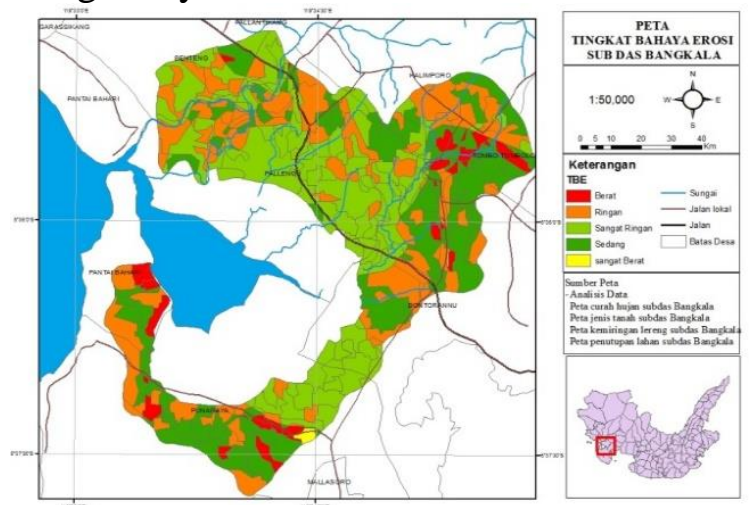

Gambar 8. Peta Tingkat Bahaya Erosi Sub DAS Bangkala

Dari analisis yang telah dilakukan diperoleh hasil bahwa sub DAS Bangkala di dominasi oleh tingkat bahaya erosi (TBE) dengan kelas sangat ringan, hal ini karena sebagian besar wilayah sub DAS Bangkala mempunyai kemiringan lereng 0$8 \%$ (datar) dengan penutupan lahan sawah, pertanian lahan kering campur dan badan air yang memiliki nilai $\mathrm{CP}$ yang rendah yaitu 0,1 dan 0,0004 .

\section{Laju Erosi Sub DAS Bangkala}

Berdasarkan hasil analisis tingkat bahaya erosi selanjutnya dilakukan analisis laju erosi untuk setiap wilayah. Pembagian wilayah ini dimaksudkan untuk mengetahui wilayah-wilayah mana saja yang berkontribusi terhadap laju erosi di sub DAS Bangkala. Laju erosi untuk setiap wilayah dapat dilihat pada Gambar 9 berikut. 


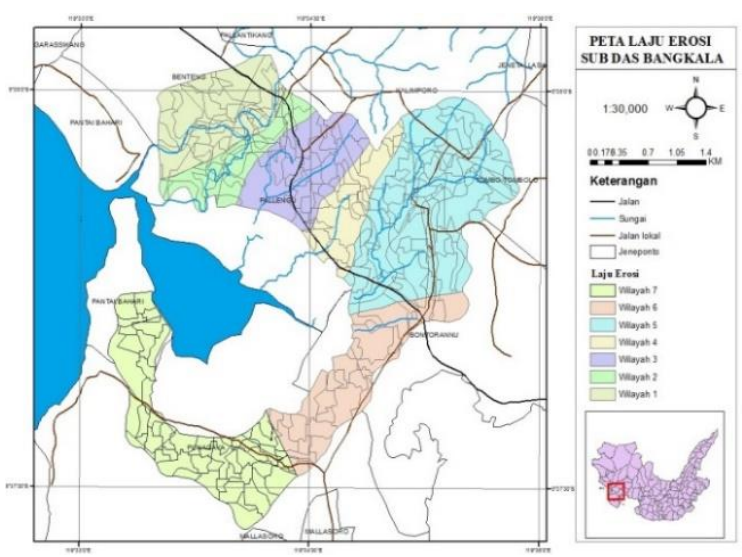

Gambar 9. Peta Laju Erosi Untuk Setiap Wilayah Sub DAS Bangkala.

Tabel 9. Laju Erosi Untuk Setiap Wilayah Sub DAS Bangkala

\begin{tabular}{|c|c|c|}
\hline Wilayah & $\begin{array}{c}\text { Laju Erosi } \\
\text { (ton/ha/tahun) }\end{array}$ & Luas (ha) \\
\hline 1 & 29,47 & 136,47 \\
\hline 2 & 35,18 & 70,21 \\
\hline 3 & 18,15 & 122,94 \\
\hline 4 & 25,09 & 75,45 \\
\hline 5 & 67,83 & 315,53 \\
\hline 6 & 41,30 & 147,43 \\
\hline 7 & 107,74 & 203,59 \\
\hline & tal & 1071,62 \\
\hline
\end{tabular}

Berdasarkan hasil analisis, wilayahwilayah yang tererosi dibagi menjadi 7 wilayah dimana wilayah 5 dan 7 merupakan wilayah yang memiliki laju erosi terbesar yaitu 67,83 ton/ha/tahun dan 107,74 ton/ha/tahun dengan luas wilayah 315,53 ha dan 203,59 ha dimana wilayah tersebut mempunyai kemiringan lereng curam dan sangat curam hal ini sesuai dengan pernyataan Kartasapoetra (2010) yang menyatakan bahwa area dengan lereng curam cenderung lebih rentan terhadap erosi daripada daerah datar atau landai.

\section{KESIMPULAN}

Hasil dari penelitian prediksi laju erosi dengan menggunakan metode RUSLE pada sub DAS Bangkala, dapat ditarik beberapa kesimpulan sebagai berikut:

1. Laju erosi sub DAS Bangkala didominasi oleh erosi sangat ringan dengan luas wilayah 391,12 ha $(36,50 \%)$.
2. Laju erosi rata-rata sub DAS Bangkala yaitu 56,05 ton/ha/tahun.

3. Terdapat beberapa daerah yang mengalami erosi yang cukup tinggi yaitu pada unit lahan 208 dan 291 (lampiran 3) yang terdapat di Desa Tombo-tombolo dan Bonto Rannu dengan besar erosi 618,54 ton/ha/tahun (3,19 ha).

4. Berdasarkan faktor-faktor penyebab terjadinya erosi, faktor yang paling berpengaruh terhadap besarnya laju erosi pada penelitian ini adalah faktor panjang dan kemiringan lereng dan faktor penutupan lahan.

\section{DAFTAR PUSTAKA}

Candra Wahyu. 2015. Kondisi Pertambakan Garam Kabupaten Jeneponto. Repository.ipb.ac.id

Fahliza Usna, Dinar Dwi Anugerah P, Sarino. 2013. Analisis Erosi Pada Subdas Lematang Hulu. Universitas Sriwijaya: Palembang.

Hardjowigeno. 2007. Ilmu Tanah. Jakarta: Akademika Pressindo

Kartasapoetra. 2010. Teknologi Konservasi Tanah dan Air. RINEKA CIPTA: Jakarta.

Suripin. 2004. Pelestarian Sumber Daya Tanah 